\title{
NASA reworks its sums after Mars fiasco
}

Washington

Confusion between imperial and metric units was to blame for the loss of the US space agency NASA's Mars Climate Orbiter, according to project managers at the Jet Propulsion Laboratory.

The spacecraft was lost on 23 September, when a targeting error sent it into, rather than safely above, the Martian atmosphere as it was about to enter orbit (see Nature 401, 415; 1999). The spacecraft was either destroyed or skipped off the atmosphere into an unknown orbit around the Sun.

A preliminary analysis has revealed that the builder of the spacecraft, Lockheed Martin Astronautics of Denver, had been supplying information about routine propulsion manoeuvres in imperial units. But NASA space navigators assumed throughout the nine-month voyage from Earth to Mars that the acceleration data were in metric units, resulting in a large targeting error when the orbiter reached its destination.

The spacecraft's operators performed a major manoeuvre to correct its trajectory a week before it reached Mars, and thought they were on course at that point. But subsequent, smaller propulsion manoeuvres were required every 15 hours or so to counteract the energy built up in onboard 'reaction wheels' used to orientate the spacecraft.

Errors in these routine smaller manoeuvres are believed to have resulted in the large deviation when the spacecraft reached Mars. Three separate review teams are currently examining the mishap in detail, with reports due in mid-November.

The first priority for NASA is to ensure that its Mars Polar Lander, also built by Lock-

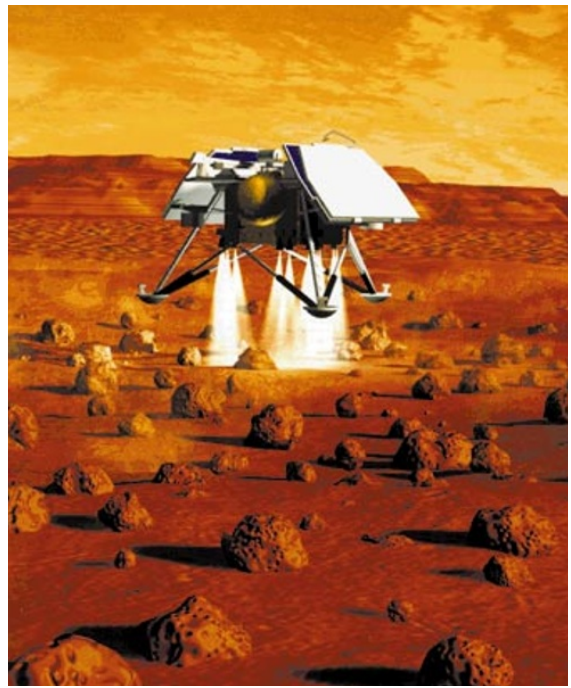

Getting it right? NASA hopes not to confuse metric and imperial for its Mars Polar Lander

heed Martin and due to touch down on the planet's surface on 3 December, does not have the same problem.

A trajectory correction planned for the lander early this month has been postponed until project engineers have a better grasp of the situation, says Noel Hinners, a vice-president at Lockheed Martin, which monitors the spacecraft from its operations centre near Denver. "We don't want to do anything until we understand this one," he says.

Unlike the Mars Climate Orbiter, the lander does not use reaction wheels to control its altitude during the interplanetary cruise, according to Hinners, so the same problem is unlikely to occur. But having made one costly mistake, Lockheed Martin is carefully scrutinizing the two missions it currently operates for NASA — the Mars Polar Lander and the Stardust comet sample return - to see if "there are any other things that could have slipped through".

The company has long experience of controlling NASA spacecraft, dating back nearly a decade to the Magellan Venus mission. But a recent external review of its Space and Strategic Missiles Sector, of which the astronautics division is a part, found systematic problems with quality control, with overemphasis on cost savings, and with management of subcontractors and parts suppliers.

The confusion between imperial and metric that doomed the spacecraft originated with a Lockheed Martin subcontractor, says Hinners. The supplier of the spacecraft's propulsion system provided accompanying data for its system in imperial units, and Lockheed Martin simply incorporated those data and passed them through the system.

"We should have caught [the mistake] then and there," he says. The propulsion system for Lockheed Martin's Mars Global Surveyor, which is now operating successfully in Martian orbit, was built by another subcontractor who used metric units.

The embarrassing mistake also underlines the lack of uniformity in the US space sector. While virtually all scientists use metric units, many US engineers, both inside and outside the space programme, use imperial units, converting them when necessary. If the United States had converted to the metric system when the subject was debated more than 20 years ago, muses Hinners, "it might have saved this mission”. Tony Reichhardt

\section{Virus treatment questioned after gene therapy death}

\section{San Francisco}

Researchers at the University of Pennsylvania are investigating the first death in a gene therapy experiment, which was revealed last week. Their enquiries centre on the adenovirus vector used to deliver potentially therapeutic DNA to the liver.

Jesse Gelsinger, an 18-year-old, highschool graduate from Arizona, developed a fever and blood clots throughout his body within hours of treatment to correct partial ornithine transcarbamylase (OTC)

deficiency, a rare metabolic disease that can cause a dangerous build-up of ammonia in the body. He died four days later.

US officials immediately began notifying the $\mathbf{1 0 0}$ or so gene therapy experimenters using adenovirus vectors, which are made using a disarmed version of the virus that causes the common cold. Both the Food and Drug Administration (FDA) and National Institutes of Health (NIH), however, stopped short of recommending any policy changes or clinical holds.

According to the protocol, researchers at the University of Pennsylvania's Institute for Human Gene Therapy used an 'E1-deleted, E2A-temperature-sensitive' adenovirus vector to infect liver cells with the normal OTC gene, which codes for a urea-cycle enzyme that removes excess nitrogen from the body.

Gelsinger, the eighteenth and final patient in the Phase I experiment, was the second person to receive a dose of $3.8 \times 10^{13}$ virus particles, believed to be the highest so far with an adenovirus. The virus was delivered by a catheter inserted into the groin artery and advanced into the vessel that feeds the liver.

Researchers at the university are reviewing their notebooks and toxicology data. They are studying the vector, treating it with restriction enzymes and testing it in primates.

They have also conducted an autopsy and are examining tissues and liver cells, looking in particular for vector-related problems because of the speed of Gelsinger's reaction. "So far, we haven't seen anything that we'd do drastically different," said Nelson Wivel, deputy directory of the University of Pennsylvania's Institute of Gene Therapy .

Inder Verma, professor of genetics at the Salk Institute in La Jolla, California, praises the Pennsylvania team for their openness, 
saying it will help to preserve public confidence and allow scientists to learn from the incident, "I'm sure it will introduce a note of caution in every experimentalist who does gene therapy, and that's a good thing," he says.

Verma describes vectors as the "Achilles heel" of gene therapy, and says that doseescalation studies using adenoviruses should be re-examined. Most gene therapy involves retroviral vectors, but adenoviruses are popular for cancer and cystic fibrosis.

Verma says he thinks vectors like the one used in the OTC trial will soon be abandoned in favour of 'gutless' adenoviruses, retroviruses, AAV or lentivectors.

A major problem of adenoviruses is that even inactivated versions can stimulate an immune response. Sustained expression of the gene is therefore impossible, and the immune system may destroy infected cells - the very cells targeted for help. The severe inflammation associated with these vectors, especially in the liver, is particularly dangerous for OTC patients.

Members of the NIH's Recombinant DNA Advisory Committee (RAC), which at

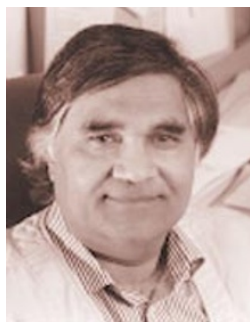

Verma: new caution is "a good thing". the time held regulatory authority over gene therapy experiments using federal funds, approved the protocol 11 to one, with four abstentions. They raised concerns about the risks of the treatment and its use — for the first time in gene therapy - in asymptomatic patients.

Individuals without the targeted gene cannot break down nitrogen, which can lead to a fatal build-up of ammonia soon after birth. The gene is X-linked - female carriers usually lead normal lives, but up to ten per cent of them could experience dangerous symptoms. Patients with partial enzyme production have done well under dietary and drug treatment.

The investigators had studied their vector in mice and primates. In the December 1995 review of the proposal for a trial in humans, RAC members discussed the potential for lethal liver inflammation based on toxicity results in Rhesus monkeys and one animal's death after an extremely high dose of a first-generation vector.

The likelihood of efficacy and the importance for this and other liver conditions convinced them to approve the study, with the recommendation that the researchers use a less invasive route of administration through a peripheral vein.

Because of concerns about infection of reproductive cells, FDA regulators made the researchers go back to treating the liver directly. Under current rules, such an experiment might be reviewed by the RAC, but only requires approval from the FDA. An FDA spokesman said that the agency cannot discuss experiments or their results without the consent of the investigators concerned.

Verma and others point to the technology's success in thousands of patients up to now, and say that the death should not be seen as a setback for gene therapy as a whole. "We would obviously prefer that this tragedy had not happened," says Wivel. "But these things do occur in cutting-edge research."

Sally Lehrman

\section{Ig prizes spawn a new generation of Nobels}

Boston

Heredity was the theme of the 'Ninth First Annual' Ig Nobel Prize ceremony at Harvard University last week, where the King and Queen of Swedish Meatballs presided as usual over the festivities.

Beach-balls, paper aeroplanes and giant doughnuts sailed through the air of a Harvard University auditorium, while Lawyers For and Against Heredity carried placards and a group of female physics students called Babes in Boyland marched in procession. In keeping with the heredity motif, descendants of famous scientists, including Francis Crick's granddaughter, took the stage.

The world premier of The Seedy Opera, a tribute to scientist and entrepreneur Richard Seed (winner of the Ig Nobel Prize for Economics in 1998), who has vowed to clone himself and other humans, was presented in four acts. Four Harvard Nobel laureates Sheldon Glashow, Robert Wilson, Dudley Herschbach and William Lipscomb played the parts of cloned sheep in the opera.

This year, Ig Nobel prizes were awarded in ten categories for work that either "cannot or should not be reproduced". Recipients came from as far afield as Australia, Japan, Norway and the United States to collect the coveted Ig prize, which resembles a plaster frog.

The science-education prize was issued jointly to the Kansas and Colorado boards of education for mandating that "children should not believe in Darwin's theory of evo-

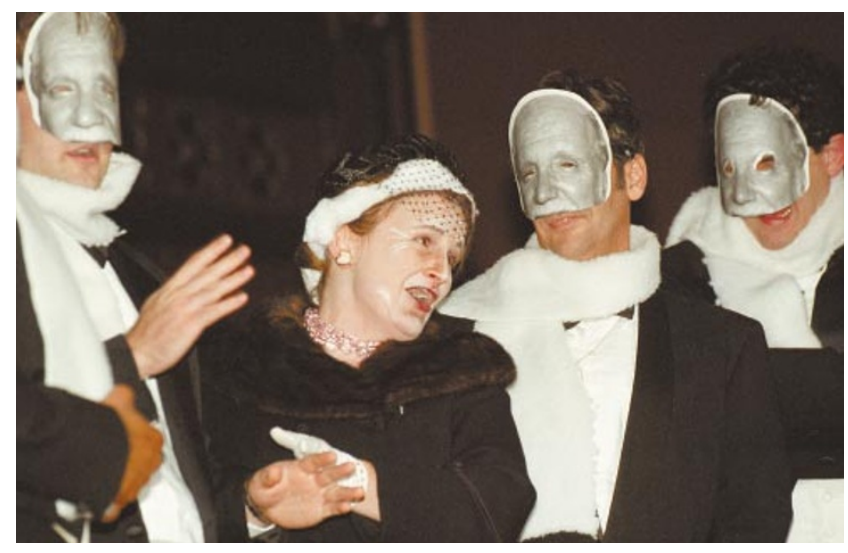

Cloning around: the world premier of The Seedy Opera, a tribute to one of last year's winners, Richard Seed, the Chicagobased former physicist who has vowed to clone himself and others.

lution, any more than they believe in Newton's theory of gravitation, Faraday's and Maxwell's theory of electromagnetism, or Pasteur's theory that germs cause disease".

Commenting on the award, University of Kansas biologist Douglas Ruden warned other states "not to let what happened in Kansas happen to you. As Dan Quayle said: 'A mind is a terrible thing to lose."'

Len Fisher of England and Australia captured one of two physics prizes, for calculating the optimal way to dunk a biscuit (see Nature 397, 469; 1999). The other award went to Jean-Marc Vanden-Broeck of the University of East Anglia for calculating how to make a teapot spout that does not drip.

Norway's Arvid Vatle earned the prize for medicine for an analysis of the containers chosen by patients for urine samples. The late
George and Charlotte Blonsky were posthumously awarded the managed health care prize for inventing a high-speed rotary chair for women in labour, to accelerate the birth process. "As chair of preventive medicine at Brigham and Women's Hospital, it's my job to prevent this kind of medicine," said JoAnn Manson of Harvard Medical School.

Takeshi Makino of Japan won the chemistry prize for developing an infidelity-detection spray for wives to apply to their husbands' underwear. The peace prize went to South Africa's Charl Fourie and Michelle Wong for inventing a car burglar alarm that comes equipped with a flame-thrower "These achievements speak for themselves," claimed master of ceremonies Marc Abrahams, editor of the science humour magazine Annals of Improbable Research. Steve Nadis 